\title{
Accommodation space, relative sea level, and the archiving of paleo-earthquakes along subduction zones
}

\author{
Harvey M. Kelsey ${ }^{1}$, Simon E. Engelhart ${ }^{2}$, Jessica E. Pilarczyk ${ }^{3,4}$, Benjamin P. Horton ${ }^{3,4}$, Charles M. Rubin ${ }^{4}$, \\ Mudrik R. Daryono ${ }^{5}$, Nazli Ismail ${ }^{6}$, Andrea D. Hawkes ${ }^{7}$, Christopher E. Bernhardt ${ }^{8}$, and Niamh Cahill ${ }^{9}$ \\ ${ }^{1}$ Department of Geology, Humboldt State University, Arcata, California 95524, USA \\ 2Department of Geosciences, University of Rhode Island, Kingston, Rhode Island 02881, USA \\ ${ }^{3}$ Department of Marine and Coastal Science, Rutgers University, New Brunswick, New Jersey 08901, USA \\ ${ }^{4}$ Earth Observatory of Singapore, Nanyang Technological University, 50 Nanyang Avenue, 639798 Singapore \\ ${ }^{5}$ Research Center for Geotechnology, Indonesian Institute of Sciences, Bandung 40132, Indonesia \\ ${ }^{6}$ Department of Physics, Syiah Kuala University, Aceh, Sumatra 23111, Indonesia \\ 7Department of Geography and Geology, University of North Carolina, Wilmington, North Carolina 28403, USA \\ ¿U.S. Geological Survey, 12201 Sunrise Valley Drive, Reston, Virginia 20192, USA \\ 9School of Mathematical Science, University College Dublin, Dublin 4, Ireland
}

\begin{abstract}
The spatial variability of Holocene relative sea-level (RSL) change influences the capacities of coastal environments to accommodate a sedimentary record of paleoenvironmental change. In this study we couch a specific investigation in more general terms in order to demonstrate the applicability of the relative sea-level history approach to paleoseismic investigations. Using subsidence stratigraphy, we trace the different modes of coastal sedimentation over the course of time in the eastern Indian Ocean where RSL change evolved from rapidly rising to static from $8000 \mathrm{yr}$ ago to present. Initially, the coastal sites from the Aceh, Sumatra, coastal plain, which are subject to repeated great earthquakes and tsunamis, built up a sedimentary sequence in response to a RSL rise of $1.4 \mathrm{~mm} / \mathrm{yr}$. The sequence found at 2 sites $8 \mathrm{~km}$ apart contained 3 soils of a mangrove origin (Rhizophora, Bruguiera/Ceriops, Avicennia pollen, and/or intertidal foraminifera) buried by sudden submergence related to coseismic subsidence and 6 tsunami sands that contain pristine subtidal and planktic foraminifera. After 3800 cal yr B.P. (years before A.D. 1950), sea level stabilized and remained such to the present. The stable relative sea level reduced accommodation space in the late Holocene, suggesting that the continued aggradation of the coastal plain was a consequence of periodic coastal inundation by tsunamis.
\end{abstract}

\section{INTRODUCTION}

The ability of a coastal environment to record successive changes in paleoenvironment associated with earthquakes and tsunamis requires stratigraphic accommodation space. Coastal sediment accumulates where accommodation space is created by relative sea-level (RSL) rise. In the Holocene, RSL change is the result of eustatic, static equilibrium, isostatic, local, and tectonic processes. The relative importance of these factors varies in space and time (Clark et al., 1978). The end of significant eustatic input from Laurentide Ice Sheet melting $7000 \mathrm{yr}$ ago slowed rates of RSL rise from $\sim 15 \mathrm{~mm} / \mathrm{yr}$ between ca. 11,400 and $8200 \mathrm{cal} \mathrm{yr}$ B.P. to $\sim 1 \mathrm{~mm} / \mathrm{yr}$ or less for the remainder of the Holocene (Lambeck et al., 2014). RSL fell in near-field areas that were covered by major ice sheets because of glacio-isostatic rebound (e.g., Long et al., 2006), while RSL in intermediate-field regions reflects the balance among postglacial isostatic recovery, proglacial forebulge collapse, and hydro-isostatic loading (Shennan and Horton, 2002). Equatorial and Southern Hemisphere RSL reconstructions recorded a mid-Holocene highstand of a few decimeters to several meters (e.g., Rostami et al., 2000), but the presence or absence of such a highstand may be controlled by local tectonic processes (Briggs et al., 2008).

Coastlines that have submerged during the Holocene (e.g., Cascadia) are excellent recorders of paleo-earthquakes and tsunamis (e.g., Witter et al., 2003) because of the subsiding coastline that provides the necessary accommodation space. In contrast, net emergent coastlines (e.g., Chile) do preserve RSL changes representative of the earthquake deformation cycle and tsunamis (e.g., Cisternas et al., 2005; Dura et al., 2015), but the lack of accommodation space makes preservation more difficult. Records of localized coseismic sub-

Figure 1. A: Location map of Sumatra, Indonesia, depicting rupture areas for the A.D. 2004 and 2005 subduction zone earthquakes (Subarya et al., 2006; Briggs et al., 2008). Bu-Burma; Th-Thailand; Ma-Malaysia; $\mathrm{M}_{\mathrm{w}}$-moment magnitude. B: Sites of paleoseismic investigations on coastal reach south of Banda Aceh. C: Pulot site, February 2005 (Google Earth ${ }^{\circledR}$ ). D: Seungko Meulat site, March 2005 (Google Earth ${ }^{\circledR}$ ). Both C and $D$ images show area denuded by December 2004 tsunami. E: Core site locations (black dots) at Pulot site. F: Core site locations (black dots) at Seungko Meulat site. sidence and accompanying tsunamis on emergent coastlines are scarce, and where discovered, fragmentary. Here we use a paleoseismic study from Aceh, Sumatra, a region that was devastated by the A.D. 2004 Aceh-Andaman earthquake and tsunami $\left(M_{w} \sim 9.2\right)$ (Subarya et al., 2006) (Fig. 1A), as an example to show the singular role that accommodation space plays in recording coastal environmental changes with time. And we show that the lack of accommodation space in a particular setting can lead to alternative strategies for determining paleoenvironmental change on tectonically active coasts. Deliberate consideration of the role that accommodation space plays in the preservation of sediments will both better focus research efforts and optimize research outcomes.

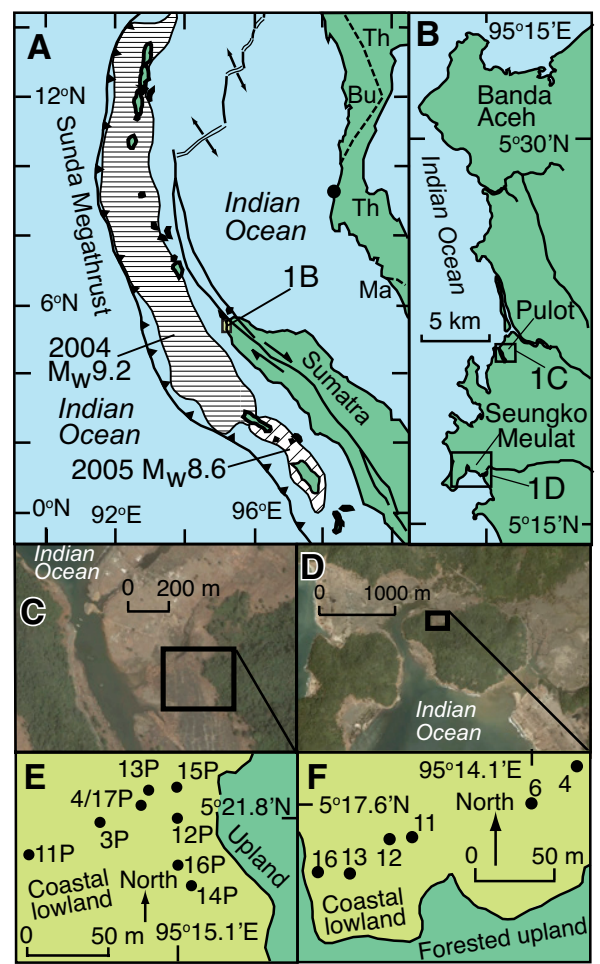




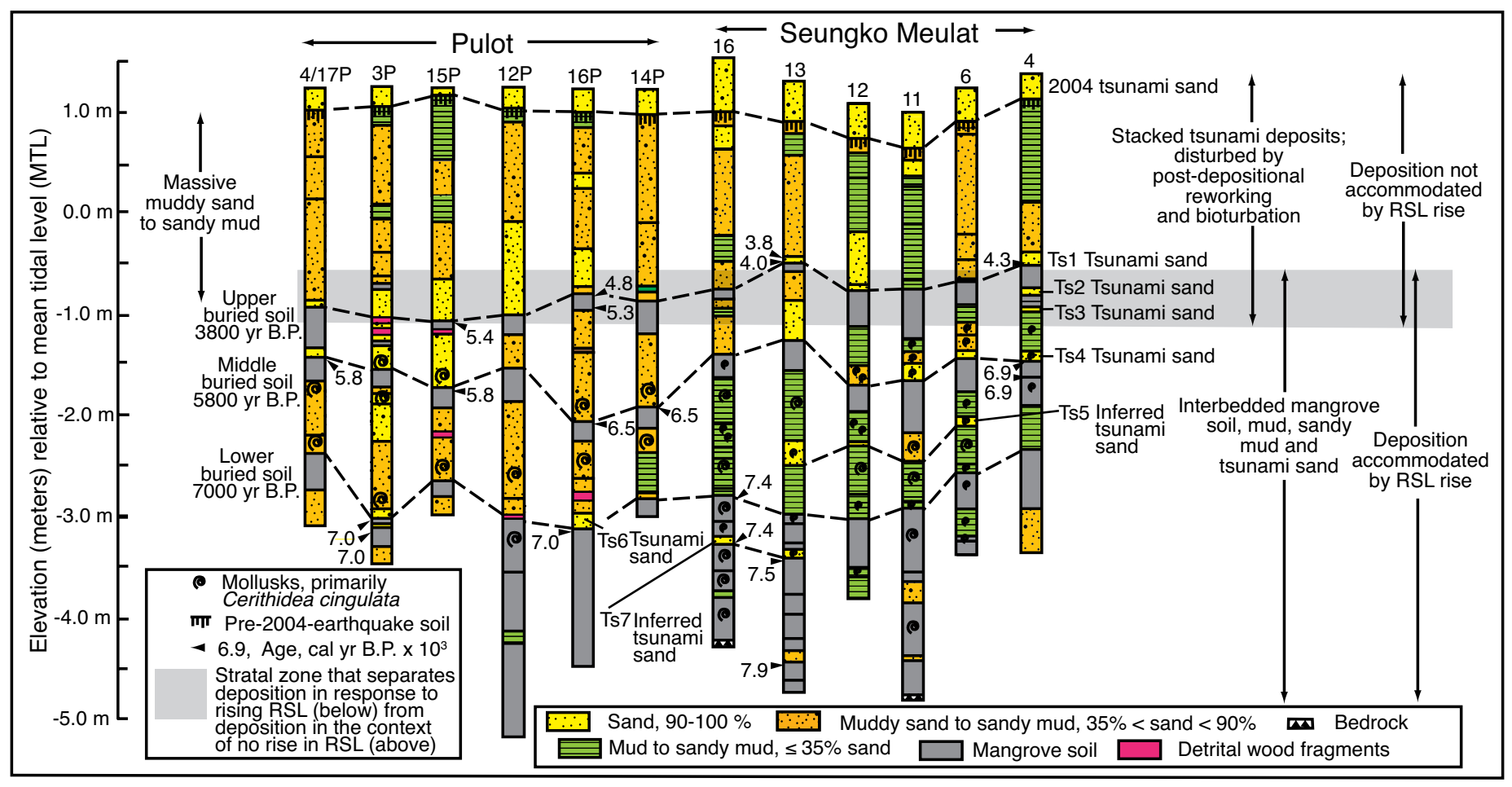

Figure 2. Correlated stratigraphy for the Seungko Meulat and Pulot sites, Aceh Province, Sumatra, Indonesia. RSL-relative sea level; Tstsunami sand. Core locations are shown in Figures 1E and 1F.

\section{ACEH COASTAL PLAIN STRATIGRAPHY}

Based on reconnaissance coring at 17 sites along the northern Aceh coast (Fig. 1B; Fig. DR1 in the GSA Data Repository ${ }^{1}$ ), we selected 2 sites $8 \mathrm{~km}$ apart (Fig. 1B; Fig. DR1) where site stratigraphy defines an early to mid-Holocene record of paleo-earthquakes and tsunamis (Fig. 2). Stratigraphy is consistent among all cores at both sites. The lower part of the stratigraphic section is dominated by three buried soils abruptly overlain by clastic units. The three buried soils are organic silts with variable but minor concentrations of fine sand and/or clay. Preserved pollen in the lower and middle buried soil at the Pulot site demonstrates a mangrove environment (e.g., Rhizophora, Bruguieral Ceriops, Avicennia pollen) (Table DR1) and supports an upper tidal environment for soil deposition (Engelhart et al., 2007). The upper buried soil was barren of pollen. We sampled detrital wood fragments for ${ }^{14} \mathrm{C}$ age determinations from the top of the each soil (Table 1; Tables DR2 and DR3). The youngest fragment represents the closest time to the burial of the soil by overlying inorganic deposits (Cisternas et al., 2005; Grand Pre et al., 2012). All dates were calibrated (cal yr B.P.) to a $2 \sigma(95 \%$ probability) error range, where zero age is A.D. 1950

${ }^{1}$ GSA Data Repository item 2015237, Tables DR1-DR5 and Figures DR1-DR6, is available online at www.geosociety.org/pubs/ft2015.htm, or on request from editing@geosociety.org or Documents Secretary, GSA, P.O. Box 9140, Boulder, CO 80301, USA.
(Reimer et al., 2013). The three soils were buried at $\sim 3800$ cal yr B.P., $\sim 5800$ cal yr B.P., and $\sim 7000$ cal yr B.P. (Fig. 2).

Sand units occur immediately above the three buried soils, as well as in two layers between the middle and upper buried soil. However, in some cases bioturbated muddy sand, rather than well sorted sand, occurs above buried soils. We infer the five sand units (Ts1, Ts2, Ts3, Ts4, and Ts6; Fig. 2; Fig. DR4) to be of local tsunami origin based upon the similarity of foraminiferal assemblages and grain size with the 2004 tsunami sand (Figs. 2 and 3; Tables DR4 and DR5). Storms are an unlikely source for the well-sorted sand because the west coast of Aceh is south of the latitude of cyclonic storms and resulting storm surges. All five inferred paleotsunami sands contain relatively high abundances of subtidal species $(72 \% \pm 9 \%)$ such as Epinoides repandus and Amphistegina spp., and planktonic species. Two additional sand layers (Ts5 and Ts7, Fig. 2; Fig. DR5) may also be of tsunami origin based on their stratigraphic context of well-sorted sand within mud.

The upper part of the stratigraphic section consists of bioturbated, massive sandy mud to muddy sand, and lacks buried soils (Fig. 2). Muddy sand is more common at the Pulot site, which is proximal to the Indian Ocean, whereas sandy mud can occur at Seungko Meulat (Fig. 3), a valley margin protected from openocean exposure (Figs. 1C and 1D). The upper part of the stratigraphic section is similar to the bioturbated massive sandy unit that some-
TABLE 1. ELEVATION AND AGE OF BURIED MANGROVE SOILS, ACEH, SUMATRA

\begin{tabular}{lcc}
\hline \hline Core site $^{\star}$ & $\begin{array}{c}\text { Elevation } \\
(\mathbf{m})^{\dagger}\end{array}$ & Sample age $^{\S}$ \\
\cline { 1 - 1 } \multicolumn{2}{l}{ Upper buried mangrove soil } & \\
\hline SM 11 13A & -0.44 & $3717-3902$ \\
SM 11 13B & -0.48 & $3844-4080$ \\
SM 11 04 & -0.46 & $4248-4421$ \\
PU 11 16 & -0.75 & $4654-4960$ \\
PU 11 16 & -0.86 & $5066-5446$ \\
PU 11 15 & -0.99 & $5301-5463$
\end{tabular}

Middle buried mangrove soil

\begin{tabular}{llll}
\hline PU 0704 & -1.35 & & $5743-5917$ \\
PU 1115 & -1.69 & & $5745-5904$ \\
PU 1114 & -1.84 & $6402-6537$ \\
PU 11 16 & -2.07 & $6409-6626$ \\
SM 11 04 & -1.59 & $6748-6958$ \\
SM 11 04 & -1.44 & $6789-6951$
\end{tabular}

Lower buried mangrove soil

PU $0703 \quad-2.96 \quad 6791-7142$

PU $1116 \quad-2.70 \quad 6912-7160$

PU $0703 \quad-3.07 \quad 6949-7166$

PU $1111 \quad-3.32 \quad 6966-7167$

PU $1119 \quad-2.33 \quad 6965-7173$

SM $1116 \quad-3.44 \quad 7320-7482$

SM $1116 \quad-2.97 \quad 7324-7475$

SM $1113 \quad-3.52 \quad 7424-7558$

PF $0712 \quad-4.87 \quad 7474-7656$

SM $1113 \quad-4.58 \quad 7837-7965$

*PU-Pulot; SM-Seungko Meulat; PF-Seudu. All core logs except PU 11, PU 13, PU 19, and PF 12 are depicted in Figure 2.

tElevation relative to mean tide level. Established by survey over $\geq 2$ tidal cycles.

$\S$ Calibrated radiocarbon age at $2 \sigma$ range

(Calib 7.0; Reimer et al., 2013), in cal yr B.P. (yr before A.D. 1950). 


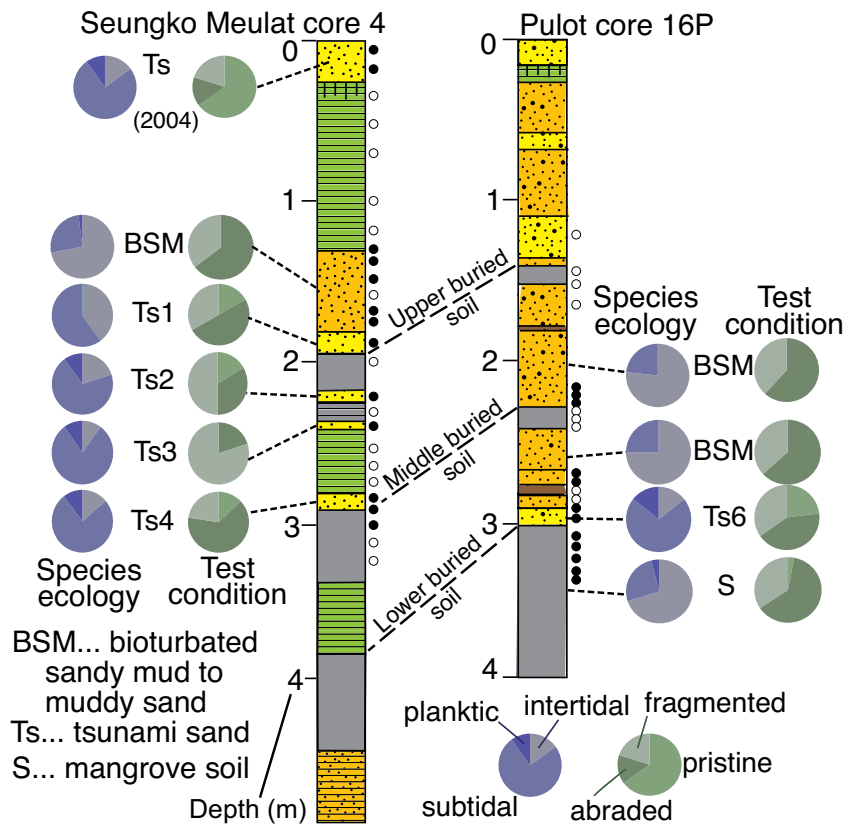

times is present above buried soils. The bioturbated massive sandy unit is distinctive from the standpoint of both foraminiferal taxonomy and taphonomy (i.e., test condition) (Fig. 3). The unit consists of an intertidal assemblage (72\% of species were intertidal) that showed evidence of subaerial exposure through a high degree of abrasion ( $65 \%$ of individuals), which is characteristic of beach and dune deposits (e.g., Berkeley et al., 2009; Pilarczyk et al., 2012). But the unit also has a relatively high abundance $(25 \%)$ of deeper dwelling subtidal (e.g., Operculina ammonoides) and planktic species that are not consistent with beach and/or dune as the sole source. Rather, we infer that the original source area of the sand is wholly or in part offshore. Given that the Aceh coast is immediately onshore of the Sunda megathrust, the most likely transport mechanism bringing subtidal foraminifera-bearing sand from offshore is a tsunami. For example, the 2004 tsunami sand, which is the uppermost stratigraphic unit, is a $15-55-\mathrm{cm}$ thick medium-fine sand dominated by subtidal (75\%) foraminifera (Figs. 2 and 3 ).

\section{RELATIVE SEA LEVELS OF ACEH, SUMATRA}

We reconstruct a 8000 yr RSL record for the coast of Aceh (Fig. 4) using sea-level index points $(\mathrm{n}=12)$ and limiting data $(\mathrm{n}=11)$ from 3 buried soils (Fig. 4; Table 1; Tables DR2 and DR3). In employing index points, we assume that coseismic subsidence is balanced out by interseismic uplift. Where foraminifera were present within the organic soils or pollen demonstrated a mangrove source, the sample was classified an index point and assigned a reference water level (RWL), which is a level halfway between highest astronomical tide (HAT) limiting data.
Figure 3. Foraminifera data; small circles depict sampling intervals. Black circles-intervals White circles-intervals where foraminifera are absent. Pie diagrams, percentages for species ecology (subtidal, planktic, intertidal) and test condition (abraded, fragmented, pristine) for bioturbated sandy mud (BSM), tsunami sand (Ts), and soil (S) are shown. Colors for stratigraphic units are as in Figure 2. containing foraminifera.

index point estimates the unique position of RSL in space and time. For each index point and limiting data point, we reconstructed RSL using the equation

$$
\mathrm{RSL}_{\mathrm{i}}=\mathrm{A}_{\mathrm{i}}-\mathrm{RWL}_{\mathrm{i}},
$$

where $A_{i}$ is the elevation of the sample measured relative to local MTL (Table 1). Each index point and limiting data point has a unique vertical error estimated from the indicative range of mangrove [(HAT-MTL)/2] (Engelhart et al., 2007) and seven other factors inherent in the collection and processing of samples for sea-level research (Shennan and Horton, 2002) (Table DR3).

The index points and limiting data points demonstrate that Holocene RSL rise in Aceh was not linear (Fig. 4). Using index points for the period 5800-7600 cal yr B.P., the overall mean rate of sea-level rise is $1.4 \mathrm{~m} / \mathrm{k}$.y. with $95 \%$ credible interval of $2.5-0.4 \mathrm{~m} / \mathrm{k}$.y. (Fig. 4; Fig. DR6). The age of the youngest index point precludes this rate continuing post-5800 cal yr B.P., when RSL was -2 m. Terrestrial limiting data points suggest that RSL was below present until at least $3800 \mathrm{cal}$ yr B.P. (Fig. 4). The high degree of abrasion of the intertidal foraminifera in the post-3800 yr sandy mud to muddy sand unit (Fig. 3), characteristic of postdepositional reworking, and the absence of coastal geomorphic features associated with a highstand suggest that RSL did not rise above present. Therefore, we infer that RSL rose slowly to present level since $3.8 \mathrm{ka}$ or stabilized within $0.4 \mathrm{~m}$ of modern RSL at 3800 cal yr B.P. (Fig. 4). Either scenario eliminates accommodation space as a driver for coastal sediment deposition after $3.8 \mathrm{ka}$.

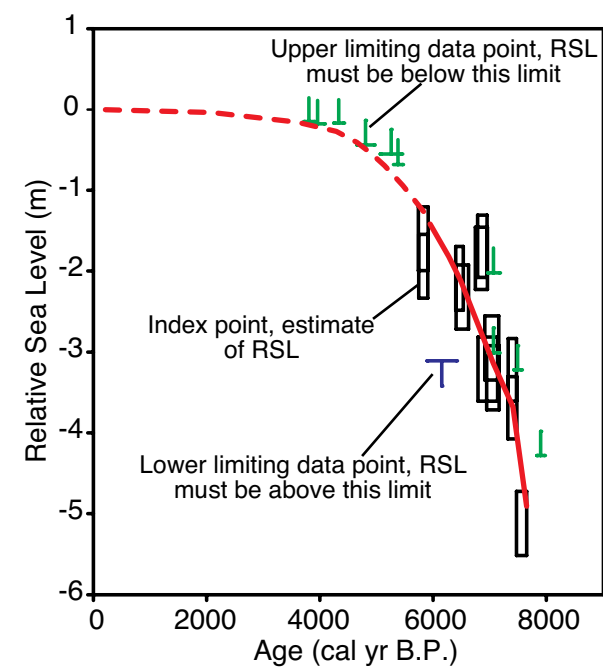

Figure 4. Aceh (Sumatra, Indonesia) relative sea-level curve. Solid line spanning 76005800 cal yr B.P. defines an overall mean rate of sea-level rise, defined by index points, of 1.4 m/k.y. (Fig. DR6; see footnote 1). Dashed line delineates the period from $5800 \mathrm{cal} \mathrm{yr}$ B.P. to present when relative sea-level (RSL) trend is constrained, to a lesser extent, by

\section{ACEH COASTAL PLAIN: PALEOSEISMIC ARCHIVES UNDER CONDITIONS OF SHRINKING ACCOMMODATION SPACE}

The beginning of the Holocene coincides with a millennial-scale period of high (to $\sim 15$ $\mathrm{mm} / \mathrm{yr}$ ) rates of global mean sea-level rise (e.g., B.P., RSL slowed sufficiently for the establishment of widespread mangrove swamps in Aceh and elsewhere in southeast Asia (e.g., Horton et al., 2005). From 8000 to 3800 cal yr B.P., the Aceh mangrove-vegetated coastal plain built upward at an average rate of $0.9 \mathrm{~m} / \mathrm{k} . \mathrm{y}$. (3.8 m sediment thickness; Fig. 2) in response to the accommodation space provided by rising RSL. Aggradation was interrupted at least three times when RSL rose instantaneously during coseismic subsidence, burying the mangrove soils with inorganic deposits (Fig. 2). Well-sorted sand preserved above buried soils is of tsunami origin, and two additional tsunamigenic sand layers occur in mud between the middle and upper buried soils (Figs. 2 and 3). The lower part of the stratigraphic section therefore records 5 subduction Lambeck et al., 2014). However, by $8000 \mathrm{cal} \mathrm{yr}$ 
zone earthquakes between 7000 and $3800 \mathrm{cal} \mathrm{yr}$ B.P., based on 5 tsunami sands, 3 of which overlie the buried soils. And a sixth and seventh additional candidate tsunami sand occurs between the lower and middle buried soils and below the lower buried soil, respectively (Fig. 2).

The 1.3-2.0-m-thick bioturbated massive muddy sand unit, which overlies the sequence of buried soils, contains mostly abraded foraminifera that are $28 \%$ subtidal (open-ocean sourced) and the rest intertidal (Fig. 3). The unit reflects aggradation of the coastal plain over the past $3800 \mathrm{yr}$ due to on-land transport of tsunami sand and subsequent reworking of both sand grains and foraminifera by tidal processes. Each subsequent tsunami further built up the coastal plain, and the 2004 tsunami is the most recent of such events.

We therefore infer that the post-3800 yr Aceh coastal plain consists of a sequence of stacked tsunami deposits (Fig. 2), the number of which depends on the recurrence of tsunamis that deposit sand. Tsunami recurrence estimates, using the underlying buried soil unit (Fig. 2) where 5-7 tsunami sands were deposited over a $3600 \mathrm{yr}$ interval from to 7400 to 3800 cal yr B.P., are 600-900 yr. If the past $3800 \mathrm{yr}$ represents the period of deposition of stacked tsunami deposits (Fig. 2), then this bioturbated massive muddy sand unit can account for 4-6 tsunamis (3800/900-3800/600). Given the 1.3$2.0 \mathrm{~m}$ thickness of the unit (Fig. 2), individual tsunami deposits would be $0.2-0.5 \mathrm{~m}$ thick if 4-6 tsunamis are represented. The 2004 tsunami deposit at the 2 study sites ranges from 0.15 to $0.55 \mathrm{~m}$ thick, which is not inconsistent with the inference that the aggraded unit represents as few as 4 or as many as 6 tsunami deposits.

\section{EXPLOITING THE FORM OF THE RSL CURVE}

Knowing the RSL record for a coastal region on a subduction zone margin is the initial step in investigating paleoseismic history. For midlatitude coasts that border subduction zones, sequences of buried soils may provide a longduration, subsidence stratigraphic paleoseismic record that spans to the present (e.g., Witter et al., 2003); but in other settings such as the Aceh coastal plain, joint research approaches, for example targeted foraminiferal analyses and palynology, are required to both exploit the changing form of the RSL curve and characterize coastal evolution in the context of the diminishing importance of accommodation space.

\section{ACKNOWLEDGMENTS}

This study received support from National Science Foundation grants EAR-0809392, EAR-0809417, and EAR-0809625. We thank E. Yulianto and D. Natawidjaja, and students and staff at Syiah Kuala University, Aceh, for field assistance. The paper was improved by comments from three anonymous reviewers and editor R. Cox.

\section{REFERENCES CITED}

Berkeley, A., Perry, C.T., and Smithers, S.G., 2009, Taphonomic signatures and patterns of test degradation on tropical, intertidal benthic foraminifera: Marine Micropaleontology, v. 73, p. 148163, doi:10.1016/j.marmicro.2009.08.002.

Briggs, R.W., Sieh, K., Amidon, W.H., Galetzka, J., Prayudi, D., Suprihanto, I., Sastra, N., Suwargadi, B., Natawidjaja, D., and Farr, T.G., 2008, Persistent elastic behavior above a megathrust rupture patch: Nias island, West Sumatra: Journal of Geophysical Research, v. 113, B12406, doi:10.1029/2008JB005684

Cisternas, M., Atwater, B.F., Torrejón, F., Sawai, Y, Machuca, G., Lagos, M., and Husni, M., 2005 , Predecessors of the giant 1960 Chile earthquake: Nature, v. 437, p. 404-407, doi: 10.1038 Inature 03943

Clark, J.A., Farrell, W.E., and Peltier, W.R., 1978, Global changes in post-glacial sea-level- $\mathrm{Nu}-$ merical calculation: Quaternary Research, v. 9, p. 265-287, doi:10.1016/0033-5894(78)90033-9.

Dura, T., Cisternas, M., Horton, B.P., Ely, L.L., Nelson, A.R., Wesson, R.L., and Pilarczyk, J.E., 2015, Coastal evidence for Holocene subductionzone earthquakes and tsunamis in central Chile: Quaternary Science Reviews, v. 113, p. 93-111, doi:10.1016/j.quascirev.2014.10.015.

Engelhart, S.E., Horton, B.P., Roberts, D.H., Bryant, C.L., and Corbett, D.R., 2007, Mangrove pollen of Indonesia and its suitability as a sea-level indicator: Marine Geology, v. 242, p. 65-81, doi: 10.1016/j.margeo.2007.02.020.

Grand Pre, C., Horton, B.P., Kelsey, H.M., Rubin, C.M., Hawkes, A., Daryono, M., Rosenberg, G. and Culver, S., 2012, Stratigraphic evidence for an early Holocene earthquake in Aceh, Indone- sia: Quaternary Science Reviews, v. 54, p. 142 151, doi:10.1016/j.quascirev.2012.03.011.

Horton, B.P., Gibbard, P.L., Milne, G.M., and Stargardt, J.M., 2005, Holocene sea levels and palaeoenvironments of the Malay-Thai Peninsula, southeast Asia: The Holocene, v. 15, p. 11991213, doi:10.1191/0959683605hl891rp.

Lambeck, K., Rouby, H., Purcell, A., Sun, Y., and Sambridge, M., 2014, Sea level and global ice volumes from the Last Glacial Maximum to the Holocene: National Academy of Sciences Proceedings, v. 111, 15296-15303, doi:10.1073 /pnas.1411762111.

Long, A.J., Roberts, D.H., and Dawson, S., 2006, Early Holocene history of the west Greenland Ice Sheet and the GH-8.2 event: Quaternary Science Reviews, v. 25, p. 904-922, doi:10.1016/j quascirev.2005.07.002.

Pilarczyk, J.E., Horton, B.P., Witter, R.C., Vane, C.H., Chagué-Goff, C., and Goff, J., 2012, Sedimentary and foraminiferal evidence of the 2011 Tōhoku-oki tsunami on the Sendai coastal plain, Japan: Sedimentary Geology, v. 282, p. 78-89, doi:10.1016/j.sedgeo.2012.08.011

Reimer, P.J., et al., 2013, IntCal13 and MARINE13 radiocarbon age calibration curves $0-50,000$ years cal BP: Radiocarbon, v. 55, p. 1869-1887, doi:10.2458/azu_js_rc.55.16947.

Rostami, K., Peltier, W.R., and Mangini, A., 2000, Quaternary marine terraces, sea-level changes and uplift history of Patagonia, Argentina: Comparisons with predictions of the ICE-4G (VM2) model of the global process of glacial isostatic adjustment: Quaternary Science Reviews, v. 19, p. 1495-1525, doi:10.1016/S0277-3791(00)00075-5.

Shennan, I., and Horton, B., 2002, Holocene landand sea-level changes in Great Britain: Journal of Quaternary Science, v. 17, p. 511-526, doi:10.1002/jqs.710.

Subarya, C., Chlieh, M., Prawirodirdjo, L., Avouac, J.-P., Bock, Y., Sieh, K., Meltzner, A.J., Natawidjaja, D.H., and McCaffrey, R., 2006, Plateboundary deformation associated with the great Sumatran-Andaman earthquake: Nature, v. 440, p. 46-51, doi:10.1038/nature04522.

Witter, R.C., Kelsey, H.M., and Hemphill-Haley, E., 2003, Great Cascadia earthquakes and tsunamis of the past 6,700 years, Coquille River estuary, southern coastal Oregon: Geological Society of America Bulletin, v. 115, p. 1289-1306, doi: 10.1130/B25189.1.

Manuscript received 12 February 2015

Revised manuscript received 21 May 2015

Manuscript accepted 24 May 2015

Printed in USA 